\title{
Coffee development strategy in the surrounding areas of Kerinci Seblat National Park (case study of Lempur Village)
}

\author{
Siti Hodijah*; Arman Delis \\ Faculty of Economics and Business, Universitas Jambi, Indonesia \\ *To whom correspondence should be addressed.Email: sitihodijahfdl@yahoo.co.id
}

\begin{abstract}
This study aimed to analyze the coffee development strategy in the surrounding areas of Kerinci Seblat National Park (KSNP). The study was conducted in Lempur Village, as one of the villages bordering KSNP. Primary data was obtained from coffee farmers and secondary data was obtained from relevant agencies. SWOT analysis was used and the data were analyzed descriptively. The study found that the main strategy in the development of coffee in Lempur Village was the expansion of the coffee marketing area. In addition to that, other strategies are needed, such as giving information about branding and guidance for independent export, promotion both through print, electronic, and social media, using better quality coffee seeds, optimizing the use of information technology to support marketing, maximizing the empowerment of farmer institutions, optimizing coffee farming management and providing training in product innovation and diversification to increase value added in production.
\end{abstract}

Keywords: branding, coffee, diversification, farmer

JEL Classification: Q12, Q13, Q18

\section{INTRODUCTION}

Kerinci is one of the regencies in Jambi Province which has the potential for the development of agricultural commodities. Various agricultural and plantation commodities are existed in this area, from vegetables such as red chili, cabbage, potatoes to plantation crops such as Cassiavera, tea, sugar cane, and coffee. Initially, Cassiavera was the main commodity, however, as time goes by this commodity has rarely been cultivated. Today farmers in Kerinci began to switch from Cassiavera to coffee.

Arabica coffee is the type of coffee that is widely planted. Coffee production in Kerinci reached 40 tons per month. It still has not been able to meet the demand for coffee from abroad, which reaches 5,000 tons per month. It means that there is a great opportunity for coffee farmers to increase their area and coffee production.

Nevertheless, Kerinci has limited land area to develop agricultural commodities, especially coffee. This is because most of Kerinci area has been claimed to be the Kerinci Seblat National Park (KSNP) area. Only 49.63 percent $(189,027.7$ ha) of the total area of Kerinci can be used as agricultural land.

Lempur is one of the villages in Kerinci regency that relies on coffee as one of its main commodities. It is located in the foothills of Gunung Raya and is a buffer zone for the KSNP (Kerinci Seblat National Park). As an area in KSNP, the selection of plantation commodities is important. The commodity must be adjusted so as not to 
damage the KSNP land. Even so, the land for coffee plantation is currently limited while demand for coffee exports continues to increase. It becomes a difficult choice for the community to increase land area without damaging the KSNP.

As an area in the TNKS region the selection of plantation commodities is important. Planting plantation commodities must be adjusted so as not to damage the KSNP land. Even so, coffee plantation land is currently limited while demand for coffee exports continues to increase making it a difficult choice for the community to increase land area without damaging the KSNP.

Coffee demand continues to increase and it is accompanied by an increase in selling prince of coffee. It encourages farmers to try increasing production from their own area. Based on this, the main objective of the study was to analyze the coffee development strategy in the surrounding area of Kerinci Seblat National Park (KSNP).

\section{RESEARCH METHODS}

This research was conducted in Lempur village, Gunung Raya district, Kerinci, Jambi Province. It used primary data and secondary data. Primary data is related to the social conditions of coffee farmers including education level of farmer, education level of their children, dependency burden of family, working hours, and income of coffee farmers. Primary data was obtained directly from observation and interviews with farmers in the production center area.

Secondary data is related to the development of area for coffee, coffee production, and number of coffee farmers. Secondary data was obtained from several publications such as Kerinci Dalam Angka, Plantation Statistics of Jambi Province, Central Bureau of Statistics of Kerinci Regency, and Kerinci Plantation Agency.

Data were analyzed descriptively to describe the socio-economic conditions of coffee farmers. SWOT analysis was done to the development strategies of coffee. The SWOT matrix describes opportunities and threats from external factors that can be adjusted to the strengths and weaknesses by SWOT. Through SWOT analysis, strategic planning can be prepared to evaluate strengths, weaknesses, opportunities, and threats in a project or a business speculation (Freddy, 2014).

\section{RESULTS AND DISCUSSION}

\section{Socio-economic conditions of coffee farmers}

The majority of coffee farmers have high school diploma. Of the total farmers, $57.14 \%$ were graduated from high school, $20.00 \%$ were graduated from junior high school, and $11.43 \%$ had undergraduate education. The relatively high level of education makes it easier for farmers to exchange experiences with fellow farmers and get more input for better farming techniques and methods.

About one third (37.14\%) of coffee farmers have relatively small dependency burden (less than 4 people) and around two-thirds (62.86\%) have large dependency burden ( 4 or more people). Coffee farmers have a lot of burden because there are dependent children who have not been married. While coffee farmers have a little burden because their children are adults and already married.

The working hours of coffee farmers are short. About $87.14 \%$ of farmers only work 5-6 hours per day. With short working hours, coffee farmers can do side jobs. While waiting for the harvest, farmers look for side jobs. Income from these side jobs is used to fulfill daily needs.

The income of coffee farmer is calculated per number of harvest, in the period of 6 months. Coffee harvesting cannot be done simultaneously. Most farmers collect the 
harvest for few months, and then mill it to separate the skin and coffee beans at one time. The peeled coffee beans are sold at Rp. $22,000 / \mathrm{kg}$.

88.57 percent of coffee farmers earn Rp. 45,000,000 or more, per harvest, while the remaining (11.43 percent) earn less than Rp. 45,000,000 per harvest. Coffee farmers use the income from coffee plantations for household use, buy luxury goods such as vehicles or build/renovate homes. The high income of farmers from coffee plantations has also increased farmers' interest in sending their children to college or university with the aim of improving family social status.

\section{Coffee development strategy in Lempur village}

In an effort to develop agribusiness of coffee, besides subsystems that support agribusiness, there are other factors that must also be considered. These factors include the availability of land, human resources as labors, the presence of local, regional, and international markets, local government support, and the availability of other supporting institutions (Hariance, et al., 2016). In this regard, various aspects of coffee development strategy in Lempur village are given as follows:

\section{Cultivation aspect}

The cultivation is the most important and most prioritized aspect to be carried out in the farming development strategy. Farming is defined as a collection of natural resources in an area that is needed to carry out agricultural production activities such as soil and water, repairs on land (e.g. weeding and fertilizing), and buildings above land and water (Mosher in Dervish, 2017).

The low productivity of coffee is due to 95 percent of coffee plantation in Indonesia being smallholder plantations, which generally don't use superior or high quality coffee seeds, simple cultivation techniques, slow rejuvenation of plants, and lack of supporting facilities and infrastructure (Nalurita, et al., 2014). In cultivation, there are three alternatives which are used as references in developing coffee farming, including counseling, revitalization of coffee land and aid of superior/high quality seeds, training in proper coffee cultivation techniques, assistance on production facilities in the right time, increased use of organic fertilizers and botanical pesticides.

The strategy that became the main priority is to improve the quality and production of coffee. Through proper cultivation, the output will have high added value. Training in coffee cultivation techniques that refers to export standards will produce higher quality of coffee. This strategy can be carried out through cultivation training, to improve and update people's knowledge about coffee cultivation.

The large number of land transfers of perennial crops to annual crops can reduce coffee production. Therefore, counseling is needed to build awareness of the importance of land as the main capital in the agricultural sector. It is also necessary to have counseling of good land management and choosing superior/high quality seeds to produce better quality output.

Aid for agricultural production facilities is a support for agricultural cultivation, such as fertilizers, seeds, equipment and other supporting tools. Assistance provided by the government includes subsidized fertilizers, seeds, and some agricultural equipment. Punctuality in distribution is very important. The distribution of fertilizers must be done when the fertilization period arrives, modern equipment must be given when the farmer is ready to use and manage it.

\section{Marketing}

Marketing is an important aspect in the development of coffee farming. The community has not been able to market its products optimally, due to the emergence of 
various internal and external constraints that hinder the process of coffee marketing directly or indirectly (Suwali, et al., 2013). Constraints that arise include the marketing area of coffee (the majority of which are still in the scale of local market), the conventional management of coffee from harvest to post-harvest, less effective management of coffee in terms of processing, packaging, and storage. In the marketing aspect, there are three alternatives. Those are including counseling/training of branding and guidance for independent exports, creating market opportunities that benefit farmers, and promoting the products widely.

Creating market opportunities that benefit farmers is the government aid to oversee the marketing process carried out by coffee farmers. Providing training and counseling is done to discuss about how to get an opportunity in the market that doesn't make farmers in loss, so they get information in terms of prices, the amount of demand for coffee, and the quality needed by the market. Promoting widelt is one of the strategies in marketing. Proof of the success in promotion is the recognition of coffee products in regional, national, and international levels, and also the ease of business access. Promotion is an important thing because it can be the beginning of open and easy access to business. Promotion can also be the strength in protecting brand rights for a product.

\section{Post-harvest handling}

Coffee becomes a commodity that is much sought after and continues to be developed. It is expected that farmers can maintain and improve the quality and quantity of coffee in order to remain a distinctive characteristic. According to Mayrowani (2013), the quality of coffee beans is expected to be in accordance with national standard of Indonesia, namely accommodating the principle of good and proper handling of post-harvest coffee beans (Good Handling Practices - GHP).

The development of technology requires farmers to play an important role and accept change, so that the commodities have competitiveness with similar products on the market. The criteria for post-harvest handling have several alternatives; those are growing awareness of proper post-harvest handling and handling assistance, training in innovation and diversification of coffee processing.

Post-harvest handling is very important after harvesting. Because of its importance, guidance to increase farmers' awareness for proper post-harvest handling is necessary. There are two types of processed coffee, i.e. wet processed coffee and dry processed coffee. The difference between two lies in its drying process. Dry processed coffee is done with wet coffee dried in the sun until it is completely dry, while wet processed coffee is done with a wet milled tool thn soaked in water repeatedly and then dried. Of the two types of processed coffee, the best one is the wet processed coffee. That is because the water content and quality of the seed can be controlled well. The processing also affected the taste and aroma of ground coffee.

Training in innovation and diversification of processed coffee is aimed to get added value of processed coffee and its cultivation. In addition to that, innovations in processed coffee can also be done with training in proper brewing of coffee (as drinks) to produce a stronger and better taste and aroma.

\section{Institutions}

Pratiwi (2016) argued that the important empowerment of farmer institutions is in the form of developing partnerships and business capital assistance. Assistance from the government and the private sector is needed in supporting and facilitating farmer partnership activities to increase cooperation partners in business networks. In this 
aspect, there are three alternatives. Those are counseling to strengthen the effectiveness of coordination between farmer institutions, capital assistance for institutions, and empowering farmer institutions to form partnerships.

Counseling to strengthen the effectiveness of coordination between farmer institutions becomes an option to facilitate the government to supervise and coordinate. Related to the capital assistance for institutions, the business problems commonly felt by farmers are a lack of capital and land. To increase farming, it is necessary to provide capital assistance that can be done through farmer groups. Besides improving their farming, farmers can also practice to manage their own group's finances and being responsible to it. However, there are difficulties for farmers to get capital assistance. It is because they only rely on their annual crops which has uncertain selling price and various conditions that are difficult to fulfill by them.

\section{Policy}

There are two alternatives related to the policy, namely the adoption of regulations on price protection and coffee trading system, and on the strengthening of coffee branding. Problem often experienced by farmers is the long marketing chain. The government should be able to formulate policies that benefit farmers in terms of marketing of crops and legal protection. Related to this, Ministry of Trade has issed Permendag No. 10/M-DAG/PER/5/2011 as amendment to Ministry of Trade Regulation No. 41/M-DAG/PER/9/2009 concerning Provisions on Coffee Exports (Sudjarmoko, 2013) with the principle of revoking provisions on payment of exporters' fees and providing convenience in reporting on export. Ministry of Agriculture in collaboration with Ministry of Trade and the International Coffee Organization (ICO) technical team has also established Indonesian national standards (SNI) and facilitated the implementation of Warehouse Receipts at the coffee production center.

The trade system that will be determinded should be able to benefit all parties involved so that no one in a disadvantage. With the adoption of regulations on price protection and coffee trading, it is hoped that it can provide a sense of security, profitability, and transparency of coffee trading. Furthermore, the adoption of regulations for strengthening coffee branding could be in the form of patent right on a product.

\section{Impact of the development of coffee plantation on the land of KSNP in Lempur Area}

The development of coffee, today, is very rapid. The demand from within the country and from abroad for coffee continue to increase every year, and even predicted to increase along with the increase in coffee consumers. With sucha a rapid market growth, it will encourage various parties, especially coffee farmers, to clear land to expand coffee plantation area and increase productivity in various ways even though it isn't environmentally friendly. It is seen by the presence of forest clearing, land conversion, and the use of chemicals such as the use of chemical fertilizers and pesticides. Although Lempur is the border of Kerinci Seblat National Park (KSNP) which has an area of 1,386,000 hectares, it doesn't make the farmers clear KSNP forest to plant coffee. People plant coffee in areas outside KSNP. If they plant in KSNP area, they will have difficulty on transport because there is no road. Maryanti (2018) argued that the farmers are aware of the importance of maintaining the KSNP area. 


\section{CONCLUSION AND RECOMMENDATION}

\section{Conclusion}

The main strategy in developing coffee in Lempur village is the expansion of the coffee marketing area. In addition to that, other strategies are needed, such as giving information about branding and guidance for independent export, promotion both through print, electronic, and social media, using better quality coffee seeds, optimizing the use of information technology to support marketing, maximizing the empowerment of farmer institutions, optimizing coffee farming management and providing training in product innovation and diversification to increase value added in production.

\section{Recommendation}

In implementing coffee development strategy, active role of all parties is needed so that the objective of increasing land productivity, product quality and farmer welfare can be realized. Also it is necessary to pay attention to environmental aspects, especially those related to the existence of KSNP which borders on coffee plantations of community.

\section{REFERENCES}

Darwis, K. (2017). Ilmu usaha tani Teori dan Penerapan. VC. Inti Mediatama. Jakarta

Freddy, Rangkuti. (2014). Analisis SWOT Teknik Pembeda Kasus Bisnis . Jakarta: PT Gramedia Pustaka Utama.

Hardiance, Rudi, et al. (2016). Strategi Pengembangan Agribisnis Kopi Robusta Di Kabupaten Solok. AGRISEP Vol. 15. No 1. Maret 2106. pp. 111-126

Nalurita, S, et al. (2014). Analisis Dayasaing dan Strategi Pengembangan Agribisnis Kopi Indonesia. Jurnal Agribisnis Indonesia Vol 2 No 1, Juni 2014: pp. 63-74.

Maryanti, Y, S, et al. (2018). Sikap dan Perilaku Masyarakat terhadap Hutan Kawasan TNKS Kecamatan Gunung Tujuh Kabupaten Kerinci. Buana - Vol-2 No-1 tahun 2018. pp. $180-191$

Mayrowani, H. (2013). Kebijakan penyediaan Teknologi Pascapanen Kopi Dan Masalah Pengembangannya. Forum Penelitian Agro Ekonomi. Vol. 31 No. 1. Juli. pp 31 - 49.

Pratiwi, R. R. (2016). Hambatan dan Strategi Pengembangan Usahatani kopi Dlam Upaya Meningkatkan Produksi. Economics Development Analysis jurnal 5 (2). pp. $207-216$.

Sudjarmoko, R. (2013). Prospek Pengembangan Industrialisasi Kopi Indonesia. SIRINOV, Vol 1, No 3, Desember 2013. pp.: 99 - 110.

Sugiono. (2012). Metode Penilaian Bisnis. Alpabet Bandung.

Suwali, et al.. (2013). Strategi Pengembangan Agroindustri Kopi Pada Gapoktan Gunung Kelir Di Kecamatan Jambu Kabupaten Semarang. Agromedia Vol. 35, No. 2 September 2017. pp $83-92$. 